\title{
Identification of Arabica Coffee Production in Altitudes Place in Lintong Ni Huta of Humbang Hasundutan
}

\author{
Ir. Adriani Siahaan, M.P \\ Student Faculty of Agricultural Doctoral Program North Sumatera
}

\begin{abstract}
Coffee is one of mainstay plantation commodities in Humbang Hasundutan Regency and as a source of countries income, providers of employment, and encourages the development of agribusiness and agroindustry. Lintong Ni Huta is one of coffee production center in Humbang Hasundutan Regency that famous with Coffee Lintong. The purpose of this study was to determine the suitability of the land and to identify the production of coffee types at various altitudes in Lintong $\mathrm{Ni}$ Huta. The results of agriculture coffee plantation and production In Lintongnihuta is the largest and most located in the villages in the altitude of 1400-1500 meters mean abaut sea level and the altitude of coffee planting in Lintongnihuta regency does not affect coffee production.
\end{abstract}

Keywords - Lintong Coffee Production, Altitudes Place.

\section{INTRODUCTION}

Coffee is a plantation crop that has long been cultivated. as well as a source of income not less than one and a half million peasants in Indonesia, coffee is also a commodity mainstay of exports and sources of foreign exchange income of the country. Indonesia's coffee now judging by the results, the fourth rank largest in the world. Coffee has a long history and has an important role for economic growth in Indonesia. Coffee (Coffea sp) Can contribute $11 \%$ of the total export of Indonesian plantation crops. Estimated area of coffee plantation exploitation in Indonesia about $1,227,787$ ha with production of 637,539 tons. North Sumatera as one of the largest coffee plantation area after South Sumatera, Lampung, Aceh and East Java with coffee plantation area of 81,474 ha with production of 60,307 tons (Directorate General of Plantation, 2017). Coffee is one of the mainstay of plantation commodities in Humbang Hasundutan Regency and has a role as a source of income of foreign countries, and sources of income, providers of employment, and encourage the development of agribusiness and agro-industry. Lintong $\mathrm{Ni}$ Huta is a coffee production center in Humbang Hasundutan regency famous for its Lintong Coffee. Coffee plantation area in this regency with $9.246 \mathrm{Ha}$ harvested area and
6,461 tons production. Coffee plantations comprise $48.45 \%$ of the area of agricultural land and plantations. (Humbahas In Figures, 2011) the development of coffee cultivation requires shade plants as a protective against direct sunlight to reduce the evapotranspiration process. Rainfall and temperature are climate factors that affect coffee production. In this case the volume and distribution of rainfall throughout the year, and the altitude of the place determines the suitability of growing coffee plants (Rothfos, 1980). The annual rainfall required for Arabica coffee growth ranges from 1,100-1,300 mm and for Robusta coffee is $1,550-2,000 \mathrm{~mm}$. Distribution of rainfall is very effected in determining the pattern of plant fertilization because it is associated with the process of breaking the dormancy of interest. While the height of the appropriate place for the growth of Arabica coffee is $1000-2000 \mathrm{~m}$ above sea level. whose temperature conditions range from $15 \mathrm{OC}$ to $24 \mathrm{OC}$, and for the Robusta coffee $<700$ MASL. whose temperature conditions range from 24 OC-30 OC (Wilson, 1985).Several factors affecting production and quality, especially on organoleptic characteristics, have not been scientifically identified, need further research to identify those prioritized factors. Organoleptic characteristic is an advantage for coffee type. The height of place, the type of soil, the climatic conditions such as temperature, humidity, until processing, storage, and marketing techniques need to be tested in relation to the quantity and quality of coffee production.

\section{LITERATURE REVIEW}

\section{Cultivation of Coffee Crops}

Economically, the growth and production of coffee plants is highly dependent on or affected by climate and soil conditions. Another basic requirement that can not be ignored is looking for superior seeds whose production is high and resistant to pests and diseases. After these requirements can be met, an important thing is maintenance, such as: fertilization, pruning, shade trees, and the eradication of pests and diseases 


\section{Varieties Coffee Sigarar Utang}

This coffee is a type of arabica coffee that thrives in mountainous areas with an altitude of $700-1700 \mathrm{~m}$ above sea level. This type of coffee is very suitable to be grown in cold climates such as in Tapanuli. Sigarar coffee plants have semi-dyed stature, short branch segments, a lush canopy covering the entire surface of the tree so that the trunk is not visible from the outside. The nature of the secondary branching is very active even the primary branch above the ground surface forming a dangling fan touching the ground. The old leaves are dark green, the young leaves (flush) are brown. When planted without leafless leaf shelves and leaf blades panting, when viewed at a glance the shape of long tapered leaves and edges of wavy leaves. Young fruit is green while the ripe fruit is bright red, round long elongated round fruit shape and 100 ripe fruit (red) on average - 196 gr. Production potential ranges from 800 to $2300 \mathrm{~kg}$ of seed / ha. Sigarar type coffee from debt is somewhat susceptible to leaf rust disease, especially grows at an altitude of less than 1000 MASL, is also susceptible to nematode parasites (Panggabean E, 2011)

\section{Soil and Climate suitable for coffee growth}

Coffee will grow if plant growth requirement can be fulfilled that is soil with effective deep enough $(>100$ $\mathrm{cm}$ ), slack, well drained, and enough water, enough nutrition, especially potassium $(\mathrm{K})$, enough organic. material $3 \%$ ). The ideal soil acidity $(\mathrm{pH})$ for coffee plant growth ranges from 5.3 to 6.5 . As long as this coffee is commonly grown in Indonesia there are two types of Robusta and arabica. Both types of coffee physiologically require requirements of different climatic conditions. Arabica coffee requires higher land than Robusta coffee, because it is grown in wetlands besides growth and productivity it is more susceptible to leaf rust disease. Arabica coffee with some criteria of planting place: High 700-1400 MASL, daily air temperature 15-24 celcius, average rainfall $2.000-4.000 \mathrm{~mm} /$ years, dry month 1-3 month / year, acidity level $(\mathrm{pH})$ soil $5.3-6$, organic matter content> $3 \%$, soil effective depth> $100 \mathrm{~cm}$, maximum slope of $40 \%$. Arabica coffee cultivation close to sea level is infected with leaf rust disease. Medium at an altitude of more than 2,000 $\mathrm{m}$ is often disturbed with dew upas. (Panggabean E, 2011). Coffee is affected by extreme season conditions, where prolonged dry seasons or excessive rain disturb flowering and fertilization. Conditions of high rainfall will disrupt the process of pollination of coffee flowers assisted by wind pollinators and beetles. Before the bloom, the physiological flowers of coffee will have a period of dormancy. At that time the flower buds stopped its development for several months (1-4 months). Factor is development of interest after the dormancy period is the availability of ground water. Although the dormancy period has passed but if the groundwater is not sufficient to the needs of division process lowers then the flowers will not bloom. The flowering process is usually triggered by the arrival of the rainy season or through the watering process (Cannell, 1985).

\section{Growing Terms}

Coffee plants have special properties because each species needs a slightly different environment. Environmental factors that greatly affect the growth of coffee plants, among others, the height of the place, rainfall, sunlight, wind, and soil (Najiyati, 2004).

\section{A. Place Height}

The actual height of the place does not directly affect the growth of the coffee plant. Air temperature factors have a direct effect on the growth of coffee plants, especially the formation of flowers and fruits and sensitivity to disease attacks. In general, high temperatures are affected by the altitude of the sea surface.

\section{b. Rainfall}

Rain is the most important climate factor after the height of the place. This factor can be seen from rainfall and rainfall time. Rainfall will affect the availability of water needed by plants.

\section{c. Sun}

In general, coffee does not like a lot of direct sunlight, but it requires sunlight that spreads / spreads. Large direct sunlight increases evaporation of soil and leaves, thus disrupting the balance of photosynthesis, especially in the dry season. In addition to its effect on photosynthesis, sunlight also affects the process of flower bud formation. A lot of sunlight will stimulate the formation of flower buds. Thus, if coffee plants throughout the year produce continuous direct sunlight then the plants will form flowers throughout the year.

As a result the flowering becomes irregular and the plant produces flowers beyond its ability so that the number of successful flowers becomes a bit of fruit.

To arrange the arrival of sunlight, usually among coffee plants grow shade plants. This shade factory is set so that coffee plants can grow in the shade and get enough sunlight.

\section{d. Wind}

The role of the wind is to help move the pollen from one plant to another with different clones. Thus, pollination occurs that can produce fruit. In addition to the positive effects on coffee plants, sometimes the wind also has a 
negative effect, especially during high winds. Strong winds will directly damage the plant canopy or abort the flowers. Strong winds that come in the dry season will also accelerate the occurrence of evapotranspiration (evaporation of water from plants and soil) resulting in drought.

e. Soil

In general, coffee plants require loose soil, fertile, and rich in organic matter. Therefore, the soil around the plant should often be given organic fertilizer to be fertile and loose so that the root system grows well. In addition to loose soil and rich in organic matter, coffee also requires a bit of acid soil, which is between $\mathrm{pH} 4.5$ to 6.5 for robusta coffee and $\mathrm{pH}$ 5-6,5 for arabica coffee. If the soil $\mathrm{pH}$ is less than that amount then the coffee plant can still grow, but less able to absorb some nutrients so the land needs to be chalked. On the other hand, the coffee plant does not want a slightly alkaline soil ( $\mathrm{pH}$ above 6.5) so that lime is not excessive (Panggabean E, 2011)

\section{METHODOLOGY}

The research was conducted in Lintong $\mathrm{Ni}$ Huta in various altitudes. The altitudes of the study sites ranged from 1200 MASL to altitude> 1500 MASL divided into several groups of places as follows: 1200 - 1300 MASL, 1300 - 1400 MASL, 1400 - 1500 MASL and > 1500 MASL. The research method is used field research that is descriptive analysis both quantitative and qualitative, the research based on solving factual problem that exist at this time. The collected data is arranged, explained, and then analyzed. Data used in this research are climate data (rainfall), area and productivity of coffee plant. This data was obtained by citing data and reports from related offices (Office of Statistics and Dishutbun Kabupaten Humbang) and taken directly from farmers as samples.

\section{Interview}

Structured interviews were conducted using questionnaires with coffee farmers. The contents of the questionnaire on research related issues are plant age, area, type of coffee grown, plant height, number of stems of tree, number of branches of tree, number of coffee beans tree branch, coffee production.

\section{RESULT AND DISCUSSION}

Growth and Production The average coffee at an altitude of 1200 - 1500 meters above sea level in Kecamatan Lintongnihuta shows not significant difference where the height of the growing place is still in accordance with the need to grow arabica coffee plants. From the results of interviews with farmers (figure 1) shows that at an altitude of 1400-1500 MASL obtained growth and better coffee production, this is possible because at the sunlight received by plants enough for photosynthesis activity and cloudy air conditions serve as a shade that prevents excessive sunlight from that received by coffee plants due to the coffee plant will produce large amounts of continuous interest in full sun exposure is also required to balance carbohydrate production to keep the fruit load as presented by DaMatta (2004) the coffee plant can become regarded as a species with widespread plasticity in response to various radiations

Table.1: Observation of Growth Conditions of Coffee Crops in each Land

\begin{tabular}{|l|c|c|c|c|}
\hline \multirow{2}{*}{\multicolumn{1}{c|}{$\begin{array}{c}\text { Identifying Growth and } \\
\text { Production of Coffee }\end{array}$}} & \multicolumn{4}{|c|}{ Altitudes (MASL) } \\
\cline { 2 - 5 } & $\mathbf{1 2 0 0 - 1 3 0 0}$ & $\mathbf{1 3 0 0 - 1 4 0 0}$ & $\mathbf{1 4 0 0 - 1 5 0 0}$ & $>\mathbf{1 5 0 0}$ \\
\hline Average Plant Height (m) & 1.54 & 1.83 & 1.67 & 1.58 \\
\hline Number of stems / trees & 1.33 & 1.00 & 1.50 & 1.21 \\
\hline Number of Branches / Trees & 19.58 & 19.58 & 22.50 & 16.67 \\
\hline Number of Coffee Beans / Branches & 45.83 & 50.83 & 85.00 & 63.33 \\
\hline Total Coffee Beans / Trees & 854.17 & 929.17 & 2066.67 & 1247.92 \\
\hline
\end{tabular}

Table.2: Characteristics and ownership of Arabica coffee plantation in some altitudes places in Kecamatan Lintong ni Huta

\begin{tabular}{|c|c|c|c|c|}
\hline \multirow{2}{*}{ Description } & \multicolumn{4}{|c|}{ Altitudes (MASL) } \\
\cline { 2 - 5 } & $\mathbf{1 2 0 0 - 1 3 0 0}$ & $\mathbf{1 3 0 0 - 1 4 0 0}$ & $\mathbf{1 4 0 0 - 1 5 0 0}$ & $>\mathbf{1 5 0 0}$ \\
\hline $\begin{array}{c}\text { a. The average age of Plants (years) : } \\
* 2-4 \\
* 5-6 \\
*>6\end{array}$ & $\sqrt{ }$ & $\sqrt{ }$ & $\sqrt{ }$ & $\sqrt{ }$ \\
\hline $\begin{array}{c}\text { b. Plant Coffee Covered other plants: } \\
* \text { Yes } \\
* \text { No }\end{array}$ & $\sqrt{ }$ & $\sqrt{ }$ & $\sqrt{ }$ & $\sqrt{ }$ \\
\hline
\end{tabular}




\begin{tabular}{|c|c|c|c|c|}
\hline 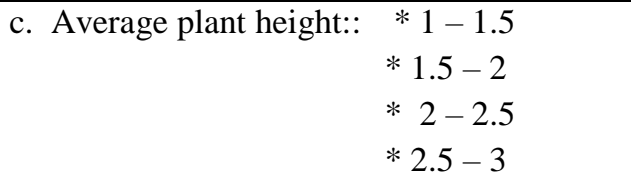 & $\sqrt{ }$ & $\sqrt{ }$ & $\sqrt{ }$ & $\sqrt{ }$ \\
\hline $\begin{array}{l}\text { d. Number Branches of tree: } \\
\qquad \begin{aligned} & * 1-5 \\
& * 5-10 \\
& * 15-25 \\
& *>25\end{aligned}\end{array}$ & $\sqrt{ }$ & $\sqrt{ }$ & $\sqrt{ }$ & $\sqrt{ }$ \\
\hline $\begin{array}{l}\text { e. Number of Coffee Beans / Branches: } \\
\qquad \begin{aligned} & * 10 \\
& * 20 \\
& * 50 \\
& * 100 \\
& *>100\end{aligned}\end{array}$ & $\sqrt{ }$ & $\sqrt{ }$ & $\sqrt{ }$ & $\sqrt{ }$ \\
\hline $\begin{array}{l}\text { f. Mean weight of seed / tree }(\mathrm{mg}) \text { : } \\
\qquad \begin{aligned} & *<250 \mathrm{mg} \\
& * 250-500 \mathrm{mg} \\
& * 500-750 \mathrm{mg} \\
& *>750 \mathrm{mg}\end{aligned}\end{array}$ & $\sqrt{ }$ & $\sqrt{ }$ & $\sqrt{ }$ & $\sqrt{ }$ \\
\hline $\begin{array}{r}\text { g. There are other plants besides coffee: } \\
\qquad \begin{array}{r}* \text { only coffee } \\
* \text { Mixing }\end{array}\end{array}$ & $\sqrt{ }$ & $\sqrt{ }$ & $\sqrt{ }$ & $\sqrt{ }$ \\
\hline $\begin{array}{ll}\text { h.Tree Density / acre: } & \\
& * 50 \\
& * 80 \\
& *>80\end{array}$ & $\sqrt{ }$ & $\sqrt{ }$ & $\sqrt{ }$ & $\sqrt{ }$ \\
\hline $\begin{aligned} & \text { i. Coffee Condition: } \\
& * \text { Pruning } \\
& * \text { fertile } \\
&\end{aligned}$ & $\sqrt{ }$ & $\sqrt{ }$ & $\sqrt{ }$ & $\sqrt{ }$ \\
\hline $\begin{array}{r}\mathrm{j} \text {. Is there a flower on the fruit stalk: } \\
* \text { Yes } \\
* \text { No }\end{array}$ & $\sqrt{ }$ & $\sqrt{ }$ & $\sqrt{ }$ & $\sqrt{ }$ \\
\hline $\begin{array}{ll}\text { k. Pests that attack: } & * \text { No } \\
& * \text { Mushroom } \\
& * \text { Insect } \\
\end{array}$ & $\sqrt{ }$ & $\sqrt{ }$ & $\sqrt{ }$ & $\sqrt{ }$ \\
\hline $\begin{array}{l}\text { 1. Types of Countermeasures: } \\
\qquad \begin{aligned} & * \text { Mechanical } \\
& * \text { Chemistry } \\
& * \text { Biological }\end{aligned}\end{array}$ & $\sqrt{ }$ & $\sqrt{ }$ & $\sqrt{ }$ & $\sqrt{ }$ \\
\hline $\begin{aligned} \text { m. Fertilization : } & \\
& * \text { once a years } \\
& * \text { twice a years }\end{aligned}$ & $\sqrt{ }$ & $\sqrt{ }$ & $\sqrt{ }$ & $\sqrt{ }$ \\
\hline $\begin{array}{l}\text { n. Type of Fertilizer: } \\
\qquad \text { Organic } \\
* \text { inorganic }\end{array}$ & $\sqrt{ }$ & $\sqrt{ }$ & $\sqrt{ }$ & $\sqrt{ }$ \\
\hline $\begin{array}{r}\text { o. Harvest forecast of the year: } \\
\qquad \begin{aligned} & * \text { Faster } \\
& * \text { Lower }\end{aligned}\end{array}$ & $\sqrt{ }$ & $\sqrt{ }$ & $\sqrt{ }$ & $\sqrt{ }$ \\
\hline $\begin{array}{r}\text { p. } \% \text { harvest compared to last year: } \\
\qquad 30 \%\end{array}$ & $\sqrt{ }$ & $\sqrt{ }$ & $\sqrt{ }$ & \\
\hline
\end{tabular}




\begin{tabular}{|c|c|c|c|c|}
\hline $\begin{array}{r}*-20 \% \\
*-10 \% \\
* 10 \%\end{array}$ & & & & \\
\hline q. Rainfall compared to last year: & & & & \\
$*-30 \%$ & $\sqrt{ }$ & & & \\
$*-20 \%$ & & $\sqrt{ }$ & $\sqrt{ }$ \\
$*-10 \%$ & & & & $\sqrt{ }$ \\
$*>10 \%$ & & & & \\
\hline
\end{tabular}

\section{Results of Farmer Questionnaire}

Farmers are still conventional and farming traditional coffee by letting coffee grow as it is. Pruning the coffee plant is still a strange thing, which is done only on plants that are not productive growth. It is necessary to change the habit and understand the usefulness of pruning as one part of care to maintain the balance of plant development in order to produce optimal fruit production. To get high quality results, the coffee picked after cooking is the time of red fruit skin. For arabica coffee the time required from flower bud formation until ready to be harvested is $6-8$ month. The average harvest data was obtained in June 2016, at the time of flowering around November-December 2015 where the number of rainy days is quite high (Table. 4) thus affecting the formation of the yielded interest slightly affecting the crop average $\%$ compared to last year. which decreased by $20 \%$ to $30 \%$. The resulting flower remains on the fruit stalk although at the time of fruit enlargement, except at altitude> 1500 MASL there is a new flower on the fruit stalk. This happens because the sunlight that continues to stimulate flowering. Higher fruit loads reduce seed size due to competition between carbohydrates during filling fruits. These results can be offset by agricultural management such as fertilization, tree pruning to help farmers improve the sustainability of coffee plantations, produce higher quality seeds and higher and ultimately increase their income. (Vaast, P, et al 2006) The altitude of the place correlates with the temperature, precipitation and soil organic matter. In relation to this condition, the higher the cultivation area, the lower the temperature and the higher the organic matter. The taste of Arabica coffee is getting better as the place grows. This condition is related to the temperature at the flowering period, the filling of the fruit, and the ripening of the fruit. This is expected to affect the taste of Arabica coffee. The higher the place also looks the better the physical quality of coffee beans indicated by the low percentage of black seeds, pests and disabilities. (Karim, A, Hifnalisa, 2012).Climate also has a big effect on coffee plant productivity. Climate effects begin to emerge from the main branch before flowering. And this continues to be felt at the opening of flowers until the path of pollination, the growth of young fruit grow old and ripe fruit, in coffee plants. Toward the dry season the weather generally starts to clear, the air is never cloudy. Because the rain has begun to fall, it means the solar radiation will be more and more, then the temperature will also increase. Primary branches (plagiotropes) of growing flowers begin to prepare for growth. Therefore, the more radiation, the preparation of the formation of flowers on coffee trees will be faster. Conversely, if irradiation decreases, preparation is slow and the amount of interest in the preparation of coffee trees is also low (Beer, J, et al., 1998) From previous research, it was found that the production to taste of coffee is determined by the way of processing, varieties, and height of the planting place (Mawardi, et al., 2008; Karim and Hifnalisa, 2011).

\section{Coffee Cultivation in Kecamatan Lintongnihuta}

The condition of coffee planting in several villages in Lintongnihuta with different height levels in Table 3 is seen at an altitude of 1200-1300 meters above sea level, only Sitio II village with planting area around 104 ha with coffee production of 60.48 tons. Area and production is lower than coffee plant in other villages such as 1,300 1400 bowls with the best coffee production of 117.48 tons from planting area of 202 ha, Siponjot village, the altitudes $1400-1500$ masl is Tapian Nauli village with Production at most 131.43 ton is generated from 226 ha of coffee planting area and $>1500$ masl altitude there is 112.82 tons of coffee production from 194 ha planting area of Dolok Margu village. The average coffee production for Kecamatan Lintongnihuta was 0.58 ton / ha. From 22 villages in Kecamatan Lintongnihuta 12 villages are located at an altitude of 1400-1500 masl with coffee cultivation area of 1570 ha, 8 villages are located at an altitude of 1300-1400 masl with an area of 885 ha of coffee and each 1 village is at an altitude of $1200-1300$ masl with coffee planting area of 104 ha and in altitude> 1500 masl there are 104 ha. The largest coffee cultivation area compared to the villages in Siponjot and Sibuntuon Partur, about $30 \%$ of the total area is coffee cultivation. Arabica Coffee Types of Sigararutang from Kecamatan Lintongnihuta have a very prominent role as a source of community income, employment and foreign exchange. Revenue of farmers / village / year average higner located in the village at an altitude of $1400-1500 \mathrm{mdpl}$ is 
Rp.4.945.683.200, Besides the height of the place, the combination of factors of plant diversity, soil type, soil fertility level where the coffee grows until the manage of the harvest crop produces a difference of production to the quality of the coffee plant. The combination of these factors is complex even from a single plantation site that finds variety in production and quality.Climate change such as temperature rise, rainfall changes affect land management and fertile soil both physically, chemically and biologically (Singh.B.P, et al, 2011)

Table.3: Characteristics of Coffee Planting in Kecamatan Lintongnihuta in various altitudes site

\begin{tabular}{|c|c|c|c|c|c|c|c|c|c|c|c|}
\hline No & Village & $\begin{array}{l}\text { Area } \\
(\mathbf{H a})\end{array}$ & $\begin{array}{c}\text { Cof } \\
\text { fee } \\
\text { Are } \\
\text { a } \\
(\text { Ha } \\
)\end{array}$ & $\begin{array}{l}\text { Altitu } \\
\text { des }\end{array}$ & $\begin{array}{l}\text { Produc } \\
\text { tion } \\
\text { (ton) }\end{array}$ & $\begin{array}{l}\text { Pop } \\
\text { ulati } \\
\text { on } \\
\text { (btg) }\end{array}$ & $\begin{array}{c}\text { Type } \\
\text { s of } \\
\text { coffe } \\
\text { e }\end{array}$ & $\mathbf{P h}$ & Type of soil & $\begin{array}{c}\text { Soil } \\
\text { Fertility } \\
\text { Rate }\end{array}$ & $\begin{array}{c}\text { Revenue } \\
\text { Farmers } \\
\text { everyVilla } \\
\text { ge / Year }\end{array}$ \\
\hline 1 & Sitio II & 541,13 & 104 & $\begin{array}{l}1200- \\
1300\end{array}$ & 60,48 & $\begin{array}{l}145 . \\
600\end{array}$ & $\begin{array}{c}\text { Arabi } \\
\text { ca }\end{array}$ & $\begin{array}{l}3.5 \\
-5\end{array}$ & $\begin{array}{c}\text { Latosol, Lithosol, } \\
\text { Podzolik }\end{array}$ & $\begin{array}{l}\text { Medium / } \\
\text { fertile }\end{array}$ & $\begin{array}{c}3.931 .345 .6 \\
00\end{array}$ \\
\hline 2 & $\begin{array}{l}\text { Nagasari } \\
\text { bu I }\end{array}$ & 689,13 & 100 & $\begin{array}{l}1300- \\
1400\end{array}$ & 58,16 & $\begin{array}{l}140 . \\
000\end{array}$ & $\begin{array}{c}\text { Arabi } \\
\text { ca }\end{array}$ & $\begin{array}{l}3.5 \\
-5\end{array}$ & $\begin{array}{c}\text { Histosol, } \\
\text { Podzolik, Latosol }\end{array}$ & $\begin{array}{l}\text { Medium / } \\
\text { fertile }\end{array}$ & $\begin{array}{c}3.780 .140 .0 \\
00\end{array}$ \\
\hline 3 & $\begin{array}{l}\text { Nagasari } \\
\text { bu II }\end{array}$ & 725,4 & 108 & $\begin{array}{l}1300- \\
1400\end{array}$ & 62,81 & $\begin{array}{l}151 . \\
200\end{array}$ & $\begin{array}{l}\text { Arabi } \\
\text { ca }\end{array}$ & $\begin{array}{l}3.5 \\
-5\end{array}$ & $\begin{array}{c}\text { Latosol, Lithosol, } \\
\text { Podzolik }\end{array}$ & $\begin{array}{l}\text { Medium / } \\
\text { fertile }\end{array}$ & $\begin{array}{c}4.082 .551 .2 \\
00\end{array}$ \\
\hline 4 & Siharjulu & $\begin{array}{c}1.235 \\
03\end{array}$ & 84 & $\begin{array}{l}1300- \\
1400\end{array}$ & 48,85 & $\begin{array}{l}117 . \\
600\end{array}$ & $\begin{array}{c}\text { Arabi } \\
\text { ca }\end{array}$ & $\begin{array}{l}4- \\
5.5\end{array}$ & $\begin{array}{c}\text { Latosol, Lithosol, } \\
\text { Podzolik }\end{array}$ & $\begin{array}{l}\text { Medium / } \\
\text { fertile }\end{array}$ & $\begin{array}{c}3.175 .317 .6 \\
00\end{array}$ \\
\hline 5 & Siponjot & 632,88 & 202 & $\begin{array}{l}1300- \\
1400\end{array}$ & 117,48 & $\begin{array}{l}282 . \\
800\end{array}$ & $\begin{array}{c}\text { Arabi } \\
\text { ca }\end{array}$ & $\begin{array}{l}4- \\
5.5\end{array}$ & $\begin{array}{c}\text { Latosol, Lithosol, } \\
\text { Podzolik }\end{array}$ & $\begin{array}{l}\text { Medium / } \\
\text { fertile }\end{array}$ & $\begin{array}{c}7.635 .882 .8 \\
00\end{array}$ \\
\hline 6 & $\begin{array}{l}\text { Nagasari } \\
\text { bu IV }\end{array}$ & 688,58 & 94 & $\begin{array}{l}1300- \\
1400\end{array}$ & 54,67 & $\begin{array}{l}131 . \\
600\end{array}$ & $\begin{array}{c}\text { Arabi } \\
\text { ca }\end{array}$ & $\begin{array}{l}3.5 \\
-5\end{array}$ & $\begin{array}{c}\text { Latosol, Lithosol, } \\
\text { Podzolik }\end{array}$ & $\begin{array}{l}\text { Medium / } \\
\text { fertile }\end{array}$ & $\begin{array}{c}3.553 .331 .6 \\
00\end{array}$ \\
\hline 7 & $\begin{array}{l}\text { Nagasari } \\
\text { bu V }\end{array}$ & 617,15 & 113 & $\begin{array}{l}1300- \\
1400\end{array}$ & 65,72 & $\begin{array}{l}158 . \\
200\end{array}$ & $\begin{array}{c}\text { Arabi } \\
\text { ca }\end{array}$ & $\begin{array}{l}3.5 \\
-5\end{array}$ & $\begin{array}{c}\text { Latosol, Lithosol, } \\
\text { Podzolik }\end{array}$ & $\begin{array}{l}\text { Medium / } \\
\text { fertile }\end{array}$ & $\begin{array}{c}4.271 .558 .2 \\
00\end{array}$ \\
\hline 8 & $\begin{array}{l}\text { Nagasari } \\
\text { bu III }\end{array}$ & 906,75 & 106 & $\begin{array}{l}1300- \\
1400\end{array}$ & 61,65 & $\begin{array}{l}148 . \\
400\end{array}$ & $\begin{array}{l}\text { Arabi } \\
\text { ca }\end{array}$ & $\begin{array}{r}3.5 \\
-5 \\
\end{array}$ & $\begin{array}{c}\text { Latosol, Lithosol, } \\
\text { Podzolik }\end{array}$ & $\begin{array}{l}\text { Medium / } \\
\text { fertile }\end{array}$ & $\begin{array}{c}4.006 .948 .4 \\
00\end{array}$ \\
\hline 9 & $\begin{array}{l}\text { Sigumpa } \\
\mathrm{r}\end{array}$ & 972,72 & 78 & $\begin{array}{l}1300- \\
1400\end{array}$ & 45,36 & $\begin{array}{l}109 . \\
200\end{array}$ & $\begin{array}{c}\text { Arabi } \\
\text { ca }\end{array}$ & $\begin{array}{l}4- \\
5.5\end{array}$ & $\begin{array}{c}\text { Latosol, Lithosol, } \\
\text { Podzolik }\end{array}$ & $\begin{array}{l}\text { Medium / } \\
\text { fertile }\end{array}$ & $\begin{array}{c}2.948 .509 .2 \\
00\end{array}$ \\
\hline 10 & $\begin{array}{l}\text { Hutasoit } \\
\text { I }\end{array}$ & 940,08 & 137 & $\begin{array}{l}1400- \\
1500\end{array}$ & 79,67 & $\begin{array}{l}191 . \\
800\end{array}$ & $\begin{array}{c}\text { Arabi } \\
\text { ca }\end{array}$ & $\begin{array}{l}4- \\
5.5\end{array}$ & $\begin{array}{c}\text { Latosol, Lithosol, } \\
\text { Podzolik }\end{array}$ & $\begin{array}{l}\text { Medium / } \\
\text { fertile }\end{array}$ & $\begin{array}{c}5.178 .791 .8 \\
00\end{array}$ \\
\hline 11 & Lobutua & 867,32 & 106 & $\begin{array}{l}1400- \\
1500\end{array}$ & 61,65 & $\begin{array}{l}148 . \\
400\end{array}$ & $\begin{array}{c}\text { Arabi } \\
\text { ca }\end{array}$ & $\begin{array}{l}4- \\
5.8\end{array}$ & $\begin{array}{c}\text { Latosol, Lithosol } \\
\text {,Podzolik }\end{array}$ & $\begin{array}{l}\text { Medium / } \\
\text { fertile }\end{array}$ & $\begin{array}{c}4.006 .948 .4 \\
00\end{array}$ \\
\hline 12 & $\begin{array}{l}\text { Pargaula } \\
\mathrm{n}\end{array}$ & 780,59 & 125 & $\begin{array}{l}1400- \\
1500\end{array}$ & 72,70 & $\begin{array}{l}175 . \\
000\end{array}$ & $\begin{array}{c}\text { Arabi } \\
\text { ca }\end{array}$ & $\begin{array}{l}4- \\
5.5\end{array}$ & $\begin{array}{c}\text { Latosol, Lithosol, } \\
\text { Podzolik }\end{array}$ & $\begin{array}{l}\text { Medium / } \\
\text { fertile }\end{array}$ & $\begin{array}{c}4.725 .175 .0 \\
00\end{array}$ \\
\hline 13 & $\begin{array}{l}\text { Sibuntuo } \\
\text { n Parpea }\end{array}$ & 630,78 & 41 & $\begin{array}{l}1400- \\
1500 \\
\end{array}$ & 23,84 & $\begin{array}{c}57.4 \\
00 \\
\end{array}$ & $\begin{array}{c}\text { Arabi } \\
\text { ca }\end{array}$ & $\begin{array}{l}4- \\
5.5\end{array}$ & $\begin{array}{c}\text { Latosol, Lithosol, } \\
\text { Podzolik }\end{array}$ & $\begin{array}{l}\text { Medium / } \\
\text { fertile }\end{array}$ & $\begin{array}{c}1.549 .857 .4 \\
00 \\
\end{array}$ \\
\hline 14 & $\begin{array}{l}\text { Sibuntuo } \\
\text { n Partur }\end{array}$ & 502,25 & 174 & $\begin{array}{l}1400- \\
1500\end{array}$ & 101,19 & $\begin{array}{l}243 . \\
600\end{array}$ & $\begin{array}{c}\text { Arabi } \\
\text { ca }\end{array}$ & $\begin{array}{l}4- \\
5.5\end{array}$ & $\begin{array}{c}\text { Latosol, Lithosol, } \\
\text { Podzolik }\end{array}$ & $\begin{array}{l}\text { Medium / } \\
\text { fertile }\end{array}$ & $\begin{array}{c}6.577 .443 .6 \\
00\end{array}$ \\
\hline 15 & $\begin{array}{l}\text { Sitolu } \\
\text { Bahal }\end{array}$ & 1.031 & 119 & $\begin{array}{l}1400- \\
1500\end{array}$ & 69,21 & $\begin{array}{l}166 . \\
600\end{array}$ & $\begin{array}{l}\text { Arabi } \\
\text { ca }\end{array}$ & $\begin{array}{l}4- \\
5.5\end{array}$ & $\begin{array}{l}\text { Latosol, Lithosol, } \\
\text { Podzolik }\end{array}$ & $\begin{array}{l}\text { Medium / } \\
\text { fertile }\end{array}$ & $\begin{array}{c}4.498 .366 .6 \\
00\end{array}$ \\
\hline 16 & $\begin{array}{l}\text { Tapian } \\
\text { Nauli }\end{array}$ & $\begin{array}{l}1.576 \\
96\end{array}$ & 226 & $\begin{array}{l}1400- \\
1500\end{array}$ & 131,43 & $\begin{array}{l}316 . \\
400\end{array}$ & $\begin{array}{c}\text { Arabi } \\
\text { ca }\end{array}$ & $\begin{array}{l}4- \\
5.5\end{array}$ & $\begin{array}{c}\text { Latosol, Lithosol, } \\
\text { Podzolik }\end{array}$ & $\begin{array}{l}\text { Medium / } \\
\text { fertile }\end{array}$ & $\begin{array}{c}8.543 .116 .4 \\
00\end{array}$ \\
\hline 17 & $\begin{array}{l}\text { Hutasoit } \\
\text { II }\end{array}$ & 729,54 & 125 & $\begin{array}{l}1400- \\
1500\end{array}$ & 72,70 & $\begin{array}{l}175 . \\
000\end{array}$ & $\begin{array}{c}\text { Arabi } \\
\text { ca }\end{array}$ & $\begin{array}{l}4- \\
5.5\end{array}$ & $\begin{array}{c}\text { Latosol, Lithosol, } \\
\text { Podzolik }\end{array}$ & $\begin{array}{l}\text { Medium / } \\
\text { fertile }\end{array}$ & $\begin{array}{c}4.725 .175 .0 \\
00\end{array}$ \\
\hline
\end{tabular}

Note: Seeds of osas / seeds without horn / ready for frying

Average gross income of farmers $/$ years $=838 \mathrm{~kg} \mathrm{x} \mathrm{Rp.} \mathrm{65,000} \mathrm{(export)}=54,470,000$

Note: Seeds of osas / seeds without horn / ready for frying

Average gross income of farmers $/$ years $=838 \mathrm{~kg} \mathrm{x} \mathrm{Rp.} \mathrm{65,000} \mathrm{(export)}=54,470,000$ 


\section{CONCLUSION}

Identification of coffee production In Lintongnihuta District is the largest and most located in the villages in altitude of 1,400-1500 meters above sea level. And the high coffee plantation in Kecamatan Lintongnihuta does not affect the production of coffee.

\section{REFERENCES}

[1] Badan Pusat Statistik, 2016. Humbahas Dalam Angka, Kab Humbang Hasundutan, Sumatera Utara

[2] Beer.J. R. Muschler, D. Kass and E. Somarriba, 1998. Shade management in coffee and cacao plantations, Agroforestry Systems 38: 139-164, Kluwer Academic Publishers. Printed in the Netherlands.

[3] Cannell, M.G.R. 1985. Physiology of the coffee crop. p. 108-134. In: M.N. Clifford \& K.C. Wilson (Eds.). Botany, Biochemistry of Beans and Beverage. AVI Publisihing, Cobbecticut, USA.

[4] DaMatta, F.M.2004. Ecophysiological constraints on the production of shaded and unshaded coffee, Field Crops Research 86: 99-114.

[5] Dishutbun, 2016. Laporan Tahunan Bidang Perkebunan Tahun 2016. Dinas Kehutanan dan Perkebunan Kab. Humbang Hasundutan, Sumatera Utara

[6] Karim, A.,Hifnalisa, 2012. Pengaruh Sifat-sifat Tanah Terhadap Citarasa Kopi Arabica, Makalah Seminar Nasional BKS PTN Wilayah Barat, Medan, 02 - 05 April 2012.

[7] Mawardi, S., Yusianto., R. Hulupi., Khalid, dan A. Marsh. 2008. Evaluasi Citarasa Beberapa Varietas Kopi Arabika pada Ketinggian Tempat dan Cara Pengolahan yang Berbeda di Dataran Tinggi Gayo (NAD). Workshop Forum Kopi Aceh. Takengon, 25 Oktober 2008.

[8] Najiyati dan Danarti. 2004. Kopi Budidaya dan Penanganan Lepas Panen, Edisi Revisi. Jakarta. Penebar Swadaya.

[9] Panggabean, E, 2011. Buku Pintar Kopi, Penerbit Agromeda, Jakarta

[10]Rothfos, B. 1980. Coffee Production. Niedersächsische buchdruckerei, Germany.366 p

[11] Singh, Bhupinder. Pal., Annette. L. Cowie., K. Yin. Chan, 2011. Soil Health and Climate Change, Soil Biology Vol. 29, Springer-Verlag Berlin Heidelberg

[12] Statistik Perkebunan Indonesia, 2016. Kopi 20152017. Penerbit Sekretariat Direktorat Jenderal Perkebunan, Kementerian Pertanian Jakarta 